\title{
Justifikasi Hukum Pidana terhadap Kebijakan Kriminalisasi Pelanggaran Hak Cipta, serta Perumusan Kualifikasi Yuridis dan Jenis Deliknya
}

\author{
Ari Wibowo \\ Fakultas Hukum Universitas Islam Indonesia \\ Jl. Tamansiswa No. 158 Yogyakarta \\ Ari_bowo1986@yahoo.com
}

\begin{abstract}
:
This study focuses on a policy of criminalization of copyright infringement through Law No. 19 of 2002 on Copyright, as well as policy formulation on juridical qualification and the type of the offense. This research includes the study of normative law with legal materials obtained through document study or literature. From the analysis, it was concluded that the theory justiying criminalization of copyright infringement is a liberalindividualistic theory which is based on social harm, as well as a moral theory that makes morality as a parameter. Moreover, no judicial qualifications emphasized the offense, as well as the determination of the crime of copyright as an ordinary offense can lead to legal problems in practice.
\end{abstract}

Key words : Criminalization policy, offense, copyright

\begin{abstract}
Abstrak
Penelitian ini difokuskan pada kebijakan kriminalisasi terhadap pelanggaran hak cipta melalui UU No. 19 Tahun 2002 tentang Hak Cipta, serta kebijakan perumusan kualifikasi yuridis dan jenis deliknya. Penelitian ini termasuk jenis penelitian hukum normatif dengan bahan hukum yang diperoleh melalui studi dokumen atau kepustakaan. Dari analisis yang dilakukan, disimpulkan bahwa teori yang menjadi justifikasi terhadap kriminalisasi pelanggaran hak cipta adalah teori liberal-individualistik yang bertumpu pada social harm, serta teori moral yang menjadikan moralitas sebagai parameternya. Selain itu, tidak ditegaskannya kualifikasi yuridis deliknya, serta penentuan tindak pidana hak cipta sebagai delik biasa dapat menimbulkan masalah hukum dalam praktiknya.
\end{abstract}

Kata kunci: Kebijakan kriminalisasi, tindak pidana, hak cipta 


\section{Pendahuluan}

Hak Kekayaan Intelektual (HKI) yang awalnya dikenal dengan Hak Milik Intelektual (HMI) merupakan suatu permasalahan yang terus berkembang seiring dengan perkembangan ilmu pengetahuan dan teknologi serta perdagangan yang sifatnya global. Pada mulanya, permasalahan HKI sangat sederhana, misalnya hanya menyangkut tuntutan untuk menguasai dan menggunakan secara mutlak sesuatu yang sudah ditemukan atau diciptakannya dengan kemampuan tenaganya maupun intelektualnya, kemudian meluas pada persoalan siapa yang berhak menjadi pemilik dari suatu hasil karya bila bahan bakunya berasal dari pihak lain, dan sebagainya. Dari waktu ke waktu permasalahan terkait HKI semakin majemuk terutama setelah terjadinya revolusi industri di Inggris dan revolusi politik di Perancis. Kedua revolusi tersebut sangat banyak memberi dorongan terhadap perkembangan asas, doktrin maupun objek perlindungan HKI. Perkembangan lain yang memberi warna sejarah perkembangan HKI, yaitu lahirnya konvensi-konvensi pada akhir abad ke-19 mengenai konvensi Hak Milik Perindustrian dan Konvensi Hak Cipta. ${ }^{1}$

Globalisasi serta perkembangan ilmu pengetahuan dan teknologi mendorong semakin berkembangnya HKI dewasa ini, bahkan menjadi lebih kompleks karena banyak dimasuki oleh berbagai kepentingan, seperti kepentingan ekonomi dan politik. Berbagai upaya gencar dilakukan oleh negaranegara maju untuk mendorong penerapan pengaturan HKI di negara-negara berkembang, misalnya dengan memberikan biaya untuk pendidikan khusus HKI di beberapa negara berkembang, bahkan seringkali klausula untuk mengefektifkan pengaturan HKI dimasukkan di dalam pembuatan perjanjian ekonomi sebagai konsekuensi timbal balik. Kondisi demikian memunculkan respon dari beberapa pihak yang berpandangan kritis bahwa HKI merupakan neokapitalisme yang syarat dengan kepentingan para kapitalis.

Indonesia merupakan salah satu negara yang menyambut baik dorongan negara-negara maju untuk menerapkan regulasi perlindungan HKI. Saat ini

1 Muhammad Djumhana dan R. Djubaedillah, Hak Milik Intelektual; Sejarah, Teori, dan Prakteknya di Indonesia, Penerbit PT. Citra Aditya Bakti, Bandung, 2003, hlm. 7. 
sudah ada beberapa undang-undang yang mengatur mengenai $\mathrm{HKI}$, diantaranya Undang-Undang Nomor 29 Tahun 2000 tentang Perlindungan Varietas Tanaman, Undang-Undang Nomor 30 Tahun 2000 tentang Rahasia Dagang, UndangUndang Nomor 31 Tahun 2000 tentang Desain Dagang Industri, Undang-Undang Nomor 32 Tahun 2002 tentang Desain Tata Letak Sirkuit Terpadu, UndangUndang Nomor 14 Tahun 2001 tentang Paten, Undang-Undang Nomor 15 Tahun 2001 tentang Merek, serta Undang-Undang Nomor 19 Tahun 2002 tentang Hak Cipta. Selain undang-undang tersebut, masih banyak lagi peraturan pelaksananya, baik dalam bentuk Peraturan Pemerintah (PP) maupun Keputusan Presiden (Keppres).

Seperangkat regulasi mengenai HKI di atas secara umum dapat dikelompokkan ke dalam dua macam hak. Pertama, Hak Cipta yang meliputi hak cipta dan hak-hak lain yang terkait dengan hak cipta. Kedua, Hak Milik Perindustrian yang meliputi Paten dan Paten Sederhana, Merk, Varietas Tanaman, Desain Industri, Desain Tata Letak Sirkuit Terpadu, dan Rahasia Dagang. Inti pengaturan di bidang HKI tersebut untuk memberikan perlindungan terhadap pemilik atau pemegang hak sebuah karya intelektual dari tindakan-tindakan "curang" yang dilakukan orang lain.

Hak Cipta yang merupakan salah satu bagian dari HKI sudah lama dikenal dan diatur dalam hukum positif Indonesia, bahkan sejak zaman Hindia Belanda dengan berlakunya Auteurswet 1912. Sejak berlakunya Auteurswet 1912 hingga sekarang, peraturan mengenai hak cipta sudah mengalami beberapa kali perubahan. Setelah Auteurswet 1912, Indonesia baru memiliki peraturan baru pada 1982, yaitu Undang-Undang No. 6 Tahun 1982 tentang Hak Cipta, kemudian diubah dengan Undang-Undang No. 7 Tahun 1987 dan diubah lagi dengan Undang-Undang No. 12 Tahun 1997 yang kemudian dicabut dan diganti dengan Undang-Undang No. 19 Tahun 2002 tentang Hak Cipta. Dengan demikian, saat ini UU yang berlaku adalah Undang-Undang No. 19 Tahun 2002 tentang Hak Cipta.

Semua undang-undang yang mengatur HKI terdapat ketentuan pidananya, termasuk di dalam Undang-Undang No. 19 Tahun 2002 atau yang 
biasa dikenal dengan Undang-Undang Hak Cipta (UUHC) 2002. ${ }^{2}$ Setiap perbuatan yang diancam dengan pidana disebut dengan tindak pidana. Adanya tindak pidana yang dirumuskan dalam sebuah peraturan perundang-undangan tentu mengandung maksud untuk melindungi suatu kepentingan hukum tertentu. Dalam UUHC 2002 terdapat 14 macam ketentuan pidana yang diatur di dalam Pasal 72.

Selain pidana, perlindungan hukum terhadap hak cipta menurut UUHC 2002 juga bersifat keperdataan. Dimuatnya hak-hak pencipta atau pemegang hak cipta untuk mengajukan gugatan perdata ke pengadilan niaga dan apa yang dapat dimintakan dalam gugatan (petitum) $)^{3}$ merupakan wujud perlindungan hukum bagi pencipta atau pemegang hak cipta dari pelanggaran-pelanggaran yang bersifat keperdataan. Dengan demikian, sengketa perdata mengenai hak cipta dapat diselesaikan di pengadilan niaga. ${ }^{4}$

Dengan adanya pengaturan pidana di dalam undang-undang hak cipta, berarti pembentuk undang-undang telah melakukan kriminalisasi ${ }^{5}$ terhadap pelanggaran hak cipta. Pada hakekatnya, kriminalisasi merupakan bagian dari kebijakan kriminal (criminal policy) dengan menggunakan sarana hukum pidana (penal), dan oleh karena itu termasuk bagian dari kebijakan hukum pidana (penal policy). ${ }^{6}$ Sebagaimana telah disebutkan di atas, bahwa dalam setiap kriminalisasi pasti ada maksud untuk memberikan perlindungan terhadap kepentingan hukum tertentu.

Kepentingan-kepentingan yang diatur hukum dapat berupa kepentingankepentingan umum (publik) atau kepentingan-kepentingan khusus (privat). Sepanjang peraturan-peraturan hukum mengatur kepentingan-kepentingan umum, maka disebut hukum publik. Sedangkan peraturan-peraturan hukum yang mengatur kepentingan-kepentingan privat, maka disebut hukum perdata.

\footnotetext{
${ }^{2}$ Ketentuan pidana terkait perlindungan hak cipta sudah dikenal sejak berlakunya Auteurswet 1912.

${ }^{3}$ Lihat Pasal 56 UU No. 19 Tahun 2002 tentang Hak Cipta.

${ }^{4}$ H. Adami Chazawi, Tindak Pidana Hak atas Kekayaan Intelektual (HAKI), Bayumedia Publishing, Malang, 2007, hlm. 15.

${ }^{5}$ Kriminalisasi adalah penetapan suatu perbuatan yang awalnya bukan merupakan tindak pidana menjadi tindak pidana. Proses ini diakhiri dengan terbentuknya undang-undang yang mengancam perbuatan tersebut dengan saksi pidana. Lihat Sudarto, Hukum dan Hukum Pidana, Alumni, Bandung, 1981, hlm. 31-32.

${ }^{6}$ Barda Nawawi Arief, Kapita Selekta Hukum Pidana, PT. Citra Aditya Bakti, Bandung, 2003, hlm. 240.
} 
Adapun hukum pidana merupakan salah satu hukum publik. ${ }^{7}$ Konsep bahwa perbuatan yang melanggar kepentingan negara sebagai representasi kepentingan publik, umumnya menjadi dasar kriminalisasi terhadap suatu perbuatan. Dengan kata lain, konsep bahwa tindak pidana adalah perbuatan yang melanggar kepentingan negara sebagai representasi kepentingan publik, menjadi dasar legitimasi kewenangan negara untuk menentukan, membuat peraturan, menuntut, menghukum seseorang yang melanggar peraturan.

Gambaran di atas memunculkan pertanyaan terkait justifikasi hukum pidana terhadap kriminalisasi pelanggaran hak cipta karena beberapa pihak beranggapan bahwa masalah hak cipta lebih condong kepada persoalan keperdataan yang masuk dalam ranah hukum privat, bukan hukum publik. Namun undang-undang hak cipta telah memasukkan pelanggaran hak cipta sebagai pelanggaran publik yang diancam dengan pidana bagi pelakunya, bahkan pelanggaran terhadap hak cipta secara yuridis dikualifikasikan sebagai delik biasa bukan delik aduan ${ }^{8}$.

Penetapan sebuah perbuatan sebagai delik biasa sebenarnya sesuai dengan sifat utama dari hukum pidana sendiri, yaitu pelaksanaannya tidak perlu digantungkan pada persetujuan atau pengaduan dari pihak yang dirugikan oleh suatu tindak pidana, melainkan diserahkan kepada aparat penegak hukum untuk menentukan apakah dan sampai dimanakah hukum pidana akan dilaksanakan, dengan mempergunakan kepentingan publik sebagai ukuran. Terlepas bagaimana sebaiknya, pastilah pembuat undang-undang memiliki alasan terhadap kriminalisasi tindak pidana hak cipta beserta kebijakan perumusan kualifikasi yuridis dan jenis deliknya.

\section{Rumusan Masalah}

Berdasarkan latar belakang yang telah diuraikan di atas, maka permasalahan yang akan diteliti dapat dirumuskan sebagai berikut: pertama, bagaimana justifikasi hukum pidana terhadap kriminalisasi pelanggaran hak

${ }^{7}$ L. J. van Apeldoorn, Pengantar Hukum Indonesia, PT Pradnya Paramita, Jakarta, 2000, hlm. 171.

8 Delik biasa berbeda dengan delik aduan yang pelaksanaan hukum pidananya bergantung pada pengaduan dari pihak yang dirugikan oleh suatu tindak pidana. 
cipta? Kedua, bagaimana kebijakan perumusan kualifikasi yuridis dan jenis deliknya?

\section{Tujuan Penelitian}

Penelitian ini bertujuan untuk, pertama, mengetahui dasar justifikasi kriminalisasi tindak pidana hak cipta dalam hukum pidana. Kedua, memahami kebijakan perumusan kualifikasi yuridis dan jenis deliknya.

\section{Metode Penelitian}

Penelitian ini termasuk jenis penelitian hukum normatif, ${ }^{9}$ dengan fokus penelitian berupa justifikasi hukum pidana terhadap kriminalisasi pelanggaran hak cipta, serta kebijakan perumusan kualifikasi yuridis dan jenis deliknya. Karena penelitian ini merupakan penelitian hukum normatif, maka data yang digunakan disebut sebagai bahan hukum ${ }^{10}$ yang terdiri dari bahan hukum primer, bahan hukum sekunder, dan bahan hukum tersier. Bahan hukum primer dalam penelitian ini adalah Undang-Undang Nomor 19 Tahun 2002 tentang Hak Cipta. Sedangkan bahan hukum sekunder terdiri dari risalah sidang Undangundang Nomor 19 Tahun 2002 tentang Hak Cipta, buku, jurnal, artikel dan literatur lainnya yang berkaitan dengan permasalahan yang dibahas. Adapun bahan hukum tersier untuk memberikan petunjuk maupun penjelasan terhadap bahan hukum primer dan bahan hukum sekunder, yaitu berupa ensiklopedia dan kamus.

9 Penelitian hukum normatif mengkaji hukum tertulis dari berbagai aspek, yaitu aspek teori, sejarah, filosofi, perbandingan, struktur dan komposisi, lingkup dan materi, konsistensi, penjelasan umum dan Pasal demi Pasal, formalitas dan kekuatan mengikat suatu undang-undang, serta bahasa hukum yang digunakan, tetapi tidak mengkaji aspek terapan atau implementasinya. Lihat Abdul Kadir Muhammad, Hukum dan Penelitian Hukum, PT Citra Aditya Bakti, Bandung, 2004, hlm. 101-102.

10 M. Syamsudin, Operasionalisasi Penelitian Hukum, PT RajaGrafindo Persada, Jakarta, 2007, hlm. 96. Sebagai perbandingan lihat juga Gregory Churchill, Dikutip dari Soerjono Soekanto, Pengantar Penelitian Hukum, UI Press, Jakarta, 2005, hlm. 51. 
Teknik pengumpulan bahan hukum yang digunakan dalam penelitian ini adalah studi dokumen atau kepustakaan. ${ }^{11}$ Sementara metode pendekatan yang digunakan adalah pendekatan filosofis, yaitu mengkaji secara mendalam latar belakang suatu aturan maupun konsep hukum dibuat, dengan mendasarkan pembahasan pada teori filsafat hukum yang berkisar pada persoalan hakekat, nilai, metode dan juga tujuan dari suatu aturan hukum. ${ }^{12}$

Sementara analisis bahan hukum yang digunakan adalah "kualitatif, komprehensif dan lengkap". Analisis kualitatif menguraikan bahan hukum dalam bentuk kalimat yang teratur, runtun, logis, tidak tumpang tindih dan efektif, sehingga memudahkan interpretasi bahan hukum dan pemahaman hasil analisis. Komprehensif berarti analisis bahan hukum secara mendalam dari berbagai aspek sesuai dengan lingkup penelitian. Sedangkan lengkap artinya tidak ada bagian yang terlewatkan, kesemuanya sudah masuk dalam analisis. ${ }^{13}$

\section{Hasil Penelitian dan Pembahasan}

\section{Perlindungan Hukum terhadap Hak Cipta}

HKI merupakan satu bentuk perlindungan atas ide atau hasil pemikiran manusia yang dimanifestasikan dalam bentuk konkrit dalam bidang industri, ilmu pengetahuan, kesenian, dan sastra. Menurut OK. Saidin, hak kekayaan intelektual adalah suatu hak kebendaan, atas suatu benda yang bersumber dari hasil kerja otak, hasil kerja rasio, hasil kerja menalar, yang mana hasil kerja tersebut dinamakan benda immaterial.14 Robert M. Sherwood juga menjelaskan bahwa secara garis besar perlindungan kekayaan intelektual mencakup dua hal. Pertama, ide, penemuan, dan ekspresi kreatif. Semua ini merupakan hasil dari usaha seseorang. Kedua, kehendak seseorang untuk melindungi hak kekayaan dari ide, penemuan, dan hasil ekspresi kreatif tersebut. Untuk mewujudkan

11 Cara pengumpulan bahan hukum dengan memeriksa atau menelusuri dokumen-dokumen atau kepustakaan yang dapat memberikan informasi atau keterangan yang dibutuhkan dalam penelitian ini. Lihat M. Syamsudin, Op.Cit., hlm. 101.

12 Ronny Hanitijo Soemitro, Metodologi Penelitian Hukum, Ghalia Indonesia, Jakarta Timur, 1985, hlm. 320.

13 Abdul Kadir Muhammad, Hukum..., Op.Cit., hlm. 127.

14 OK. Saidin, Aspek Hukum Hak Kekayaan Intelektual (Intellectual Property), Raja Grafindo Persada, Jakarta, 2006, hlm. 9. 
perlindungan tersebut maka bisa menggunakan rahasia dagang, paten, hak cipta dan lain-lain. Dengan demikian, ada dua konsep dalam kekayaan intelektual, yaitu konsep kreativitas individu dan konsep perlindungan publik terhadap kreativitas tersebut. Dengan kata lain menurut Robert M. Sherwood bisa dibuat rumus bahwa penemuan dan ekspresi kreatif ditambah perlindungannya sama dengan kekayaan intelektual. ${ }^{15}$ Sehingga secara umum tujuan dari sistem HKI, termasuk hak cipta adalah melindungi pencipta dan juga memberikan sebuah aturan kepada pihak di luar pencipta untuk bisa mengakses ciptaan tersebut. ${ }^{16}$

Gagasan untuk memberikan perlindungan sekaligus penghargaan kepada pencipta atas hasil ciptaannya yang kemudian menjadi teori yang menjustifikasi hak cipta muncul pada abad keempat sebelum Masehi. Gagasan ini dikemukakan oleh John Locke yang mengatakan bahwa sudah sepatutnya seseorang memiliki hak milik terhadap benda yang dihasilkannya. ${ }^{17}$ Sedangkan benda yang dirumuskan oleh John Lock adalah benda yang tidak hanya berbentuk fisik melainkan juga benda yang sifatnya non fisik yang disebut juga dengan hak milik atas benda yang tidak berwujud. ${ }^{18}$ Dengan perkataan lain bahwa seseorang yang telah mengeluarkan usaha ke dalam penciptaan memiliki sebuah hak alami untuk memiliki dan mengontrol apa yang telah mereka ciptakan. Pendekatan ini menekankan pada kejujuran dan keadilan. Dilihat sebagai perbuatan yang tidak jujur dan tidak adil jika mengambil usaha seseorang tanpa mendapatkan terlebih dahulu persetujuannya. ${ }^{19}$

Menurut teori hukum alam yang diusung oleh John Locke, sudah menjadi sebuah hal yang sifatnya kodrati jika seorang manusia yang dengan kerja keras pikirannya bisa menciptakan sesuatu, maka hasil ciptaanya menjadi milik pencipta dan atas hasil ciptaan tersebut pencipta memiliki hak untuk menikmati hasilnya termasuk juga keuntungan yang dihasilkannya. Selain itu, pencipta juga

${ }^{15}$ Robert M. Sherwood, Intellectual Property and Economic Development, Alexandria, Virginia, 1990, hlm.11-12.

${ }^{16}$ Mahesh Mandhavan, “Intellectual Property Rights: An Overview” dalam JISC Legal Journal, March 2006, hlm. 1.

${ }_{17}^{17}$ Rahmi Jened, Perlindungan Hak Cipta Pasca TRIPs, Fak. Hukum Unair, Surabaya, 2001, hlm. 15.

18 Syafrinaldi, Hukum Tentang Perlindungan Hak Milik Intelektual Dalam Menghadapi Era Globalisasi, UIR Press, Pekanbaru, 2001, hlm. 6.

${ }^{19}$ Tim Lindsey dkk (ed.), Hak Kekayaan Intelektual Suatu Pengantar, P.T Alumni, Bandung, 2002, hlm. 13. 
mempunyai hak untuk mempertahankan hak yang dimilikinya tersebut, sehingga hak cipta ini adalah satu bentuk pemberian hak esklusif atas satu karya cipta. ${ }^{20}$

Ada beberapa teori lain yang menjadi dasar perlindungan terhadap hak cipta. Beberapa teori tersebut diantaranya adalah reward theory, recovery theory dan incentive theory. Menurut reward theory, pencipta atau inventor harus dilindungi sebagai penghargaan dari usahanya. Hal ini merupakan bentuk penghargaan publik terhadap prestasi individu seseorang. Seorang pemikir, penulis, atau penemu suatu hal secara etika harus diberikan penghargaan (reward) khususnya bagi yang menikmati manfaat dari yang dihasilkan tersebut. Penghargaan ini sebagai dorongan agar masyarakat dapat lebih bersemangat untuk berprestasi dengan menghasilkan karya cipta yang bermanfaat bagi masyarakat. ${ }^{21}$

Sedangkan recovery theory menyatakan bahwa mungkin tanpa pengorbanan yang berupa usaha keras, waktu, dan uang, seorang pencipta atau inventor tidak mungkin bisa menciptakan suatu karya cipta. Dengan demikian, maka sudah sewajarnya kalau pencipta atau inventor mendapatkan kesempatan dalam memulihkan keadaannya seperti semula, atau pengembalian terhadap apa yang telah ia keluarkan dalam menciptakan suatu karya cipta. ${ }^{22}$

Teori yang ketiga adalah incentive theory yang mengutamakan pada keberlanjutan suatu ciptaan. Jadi, dengan adanya insentif bagi seorang pencipta, diasumsikan akan memberikan dorongan kepada pencipta untuk menghasilkan karyanya lebih baik lagi. Dengan kata lain, insentif ini bisa dikatakan sebagai pemicu semangat bagi seorang pencipta untuk menciptakan karya cipta yang lebih dari sebelumnya. ${ }^{23}$

Teori lain yang dapat dipakai adalah risk theory. Menurut teori ini, beberapa karya cipta berhasil diciptakan melalui proses kerja yang penuh resiko. Sering kali suatu karya diciptakan melalui beberapa kali kegagalan bahkan dapat membuat frustasi penciptanya. Itulah beberapa resiko dalam proses penciptaan suatu karya cipta. Oleh karena itu, resiko yang telah ia alami haruslah

\footnotetext{
20 Marshal Leaffer, Understanding Copyright Law Mattew, Bender, New York, 1998, hlm. 14.

${ }^{21}$ Robert M Sherwood, Op.Cit., hlm. 37.

22 Ibid., hlm. 38.

${ }^{23}$ Ibid.
} 
mendapatkan kompensasi dari orang lain yang memanfaatkan karya ciptanya. ${ }^{24}$ Dengan adanya beberapa teori yang digunakan sebagai dasar dalam pemberian perlindungan tersebut maka pencipta mempunyai hak ekslusif. Hak ekslusif tersebut adalah hak untuk mengumumkan, memperbanyak, atau menyewakan hasil ciptaannya.

Selain beberapa teori di atas, Universal Declaration of Human Right 1948 yang dianggap sebagai peraturan tertinggi dunia tentang HAM juga memberikan landasan untuk perlindungan hasil ciptaan manusia. Dalam Universal Declaration of Human Right disebutkan bahwa: "(1) Everyone has the right freely to participate in the cultural life of the community, to enjoy the arts and to share in scientific advancement and its benefits; (2) Everyone has the right to the protection of the moral and material interst resulting from any scientific, literary, or artistic production of which he is the author. ${ }^{25}$

\section{Justifikasi Kriminalisasi terhadap Pelanggaran Hak Cipta}

Dengan adanya beberapa teori dan Universal Declaration of Human Right 1948 yang menjadi dasar perlindungan hukum terhadap hak cipta, maka dasar hukum pemberian perlindungan atas kekayaan intelektual yang dimanifestasikan ke dalam satu bentuk ciptaan menjadi semakin kuat karena perlindungan tersebut juga merupakan hak asasi yang kedudukannya sama dengan hak untuk hidup dan hak untuk mendapatkan pekerjaan yang layak. ${ }^{26}$ Namun kemudian yang menjadi persoalan, apakah perlindungan terhadap suatu karya cipta dengan sarana penal (hukum pidana) memiliki justifikasi yang kuat, sehingga dibenarkan adanya kriminalisasi terhadap pelanggaran hak cipta.

Untuk menjawab persoalan di atas perlu dicermati Penjelasan UndangUndang No. 19 Tahun 2002 tentang Hak Cipta (UUHC 2002) yang menyebutkan bahwa maksud dari pembuatan undang-undang memberikan perlindungan terhadap hak cipta, yaitu: 1. Indonesia sebagai Negara kepulauan memiliki keanekaragaman seni dan budaya yang kaya. Hal itu sejalan dengan etnik, suku bangsa, dan agama yang secara keseluruhan merupakan potensi nasional yang

${ }^{24}$ Ibid., hlm. 38-39.

25 Pasal 27 Universal Declaration of Human Right 1948.

${ }^{26}$ Dalam UUHC 2002 disebutkan tujuan pengaturan perlindungan karya cipta melalui UU adalah untuk memberikan perlindungan. 
perlu dilindungi. Kekayaan seni dan budaya itu merupakan salah satu sumber dari kekayaan intelektual yang dapat dan perlu dilindungi oleh undang-undang; 2. Indonesia telah ikut dalam pergaulan masyarakat dunia dengan menjadi anggota dalam Agreement Eshtablishing The World Trade Organization yang mencakup pula Agreement on Trade Related Aspects of Intellectual Property Right (TRIPs) melalui Undang-Undang No. 7 Tahun 1994. Selain itu, Indonesia juga telah meratifikasi beberapa konvensi internasional lain yang terkait dengan hak cipta (property right). ${ }^{27}$

Melihat pertimbangan kedua Penjelasan UUHC 2002 dapat disimpulkan bahwa Indonesia dalam membuat rumusan UUHC mendasarkan pada ketentuan TRIPs (Agreement on Trade Related Aspects of Intellectual Property Right) yang telah diratifikasi oleh Indonesia dengan Undang-Undang No. 7 Tahun 1994. ${ }^{28}$ TRIPs menentukan norma-norma dan standar substantif minimum mengenai bagaimana perlindungan diberikan dan bagaimana perlindungan tersebut diaplikasikan. Sepanjang tidak bertentangan dengan TRIPs, negara anggota dapat menerapkan norma-norma atau standar substantif yang melebihi dari yang diharuskan oleh TRIPs dalam hukum nasionalnya.

Pengaturan sanksi pidana sebagaimana dipergunakan dalam kebijakan kriminalisasi terhadap tindak pidana hak cipta di Indonesia memiliki dasar pijakan sebagaimana diatur dalam TRIPs, yaitu:

Members shall provide for criminal procedures and penalties to be applied at least in cases of wilful trademark counterfeiting or copyright piracy on a commercial scale.... Members may provide for criminal procedures and penalties to be applied in other cases of infringement of intellectual property right, in particular where they are committed wilfully and on a commercial scale. ${ }^{29}$

Dengan demikian, sesungguhnya TRIPs lebih mengutamakan penerapan pidana pada pelanggaran pemalsuan merek dagang atau pembajakan hak cipta untuk kegiatan komersil yang dilakukan dengan sengaja (dolus). Sementara untuk yang lainnya hanya merupakan pilihan kebijakan untuk ditempuh atau tidak oleh negara-negara anggota.

\footnotetext{
${ }^{27}$ Lihat penjelasan UUHC 2002.

${ }^{28}$ Lihat Penjelasan UUHC 2002.

${ }^{29}$ Lihat TRIPs, part III, section 5, article 61.
} 
Indonesia sendiri sebenarnya telah menerapkan pidana pada pelanggaran hak cipta sebelum TRIPs disetujui dan diratifikasi pada tahun 1994. Penerapan pidana terhadap pelanggaran hak cipta sudah digunakan oleh Indonesia sejak berlakunya Auteurswet 1912 dan tetap dipertahankan di dalam UU No. 6 Tahun 1982 tentang Hak Cipta, UU No. 7 Tahun 1987, UU No. 12 Tahun 1997 sampai UU No. 19 Tahun 2002 tentang Hak Cipta yang berlaku saat ini, bahkan pidananya semakin diperberat.

Menurut L. J. Van Apeldoorn, isi peraturan-peraturan hukum bergantung kepada hakekat kepentingan-kepentingan yang diatur oleh hukum. Kepentingankepentingan yang diatur hukum dapat berupa kepentingan-kepentingan umum (publik) atau kepentingan-kepentingan khusus (privat). Sepanjang peraturanperaturan hukum mengatur kepentingan-kepentingan umum, maka ia disebut hukum publik. Sedangkan sepanjang peraturan-peraturan hukum mengatur kepentingan-kepentingan privat, maka ia disebut hukum perdata. Hukum pidana termasuk di dalam hukum publik, ${ }^{30}$ sehingga hukum pidana merupakan perangkat norma yang mengatur kepentingan-kepentingan yang bersifat umum (publik). Dalam prosedur acara pidana, jaksa penuntut umum bertindak mewakili negara dalam membela kepentingan umum.

Doktrin yang diungkapkan L. J. Van Apeldoorn di atas sulit untuk dijadikan sebagai justifikasi kriminalisasi terhadap pelanggaran hak cipta karena perlindungan terhadap hak cipta sebenarnya lebih kepada perlindungan terhadap kepentingan yang bersifat pribadi (privat) dimana perlindungannya seharusnya menggunakan instrumen hukum perdata. Pasal 56 UUHC 2002 juga mengakui bahwa pelanggaran terhadap hak cipta memiliki unsur pelanggaran terhadap kepentingan individu, sehingga pencipta atau pemegang hak cipta dapat mengajukan gugatan perdata ke pengadilan niaga terhadap pelanggar hak ciptanya. Namun demikian, doktrin kepentingan umum sebagai justifikasi kebijakan kriminalisasi terhadap suatu perbuatan sudah hampir ditinggalkan oleh banyak negara. Doktrin kepentingan umum sudah mulai bergeser kepada teori-teori kriminalisasi lain yang berkembang saat ini, diantaranya adalah teori liberal-individualistik dan teori moral.

${ }^{30}$ L. J. van Apeldoorn, Op.Cit., hlm. 171. 
Teori liberal-individualistik memiliki titik tolak yang sama dengan dasar teori kriminalisasi yang dikemukakan Beccaria, yaitu prinsip kerugian. Dalam menjelaskan teorinya, Beccaria memakai istilah "injury done to society", sementara dalam teori liberal-individualistik digunakan istilah "social harm" atau "harm to society". Menurut Jerome Hall, "social harm" merupakan kata kunci untuk menyebut suatu perbuatan sebagai kejahatan. ${ }^{31}$

Pemikiran John Stuart Mill menjadi rujukan teori liberal-individualistik. Dalam bukunya On Liberty, Mill menegaskan bahwa kekuasaan negara untuk mengatur masyarakat dibatasi oleh kebebasan warganegara. Negara hanya boleh campur tangan terhadap kehidupan pribadi warganegara bila warganegara tersebut merugikan kepentingan orang lain. Jika tindakan seseorang tidak merugikan orang lain, maka tidak boleh ada pembatasan terhadap kebebasannya, tetapi jika suatu tindakan merugikan orang lain, maka negara berwenang untuk mengkriminalisasikannya. ${ }^{32}$

Kalau diterapkan dalam persoalan hak cipta, maka teori liberalindividualistik ini dapat menjadi justifikasi kriminalisasi terhadap pelanggaran hak cipta karena dapat merugikan orang lain. Pihak yang dirugikan tentunya para pencipta karya cipta yang berdasarkan teori hukum alam, rewarad theory, recovery theory, incentive theory dan risk theory, berhak mendapatkan perlindungan terhadap karya cipta yang telah ia ciptakan melalui suatu proses yang memerlukan tenaga dan pikiran bahkan modal yang bersifat materi.

John Lock berpendapat bahwa umumnya semua orang memiliki kewajiban untuk tidak merugikan orang lain kecuali dalam kasus khusus dan kebutuhan yang sangat mendesak yang dapat dibenarkan. Hak untuk tidak dirugikan (the right not to be harmed) secara leksikal ada sebelumnya sebagai hak alamiah. Ada dua kunci hak bebas, yakni: "all persons have a liberty right to dispose of their efforts as they see fit dan all persons have a liberty right to use the common; the earth and all its fruit which God give to humankind." 33 Dengan demikian maka tidak boleh ada orang

\footnotetext{
31 Salman Luthan, Op.Cit., hlm. 82.

32 Ibid.

33 Rahmi Jened, Hak Kekayaan Intelektual Penyalahgunaan Hak Eksklusif, Airlangga University Press, Surabaya, 2007, hlm. 16-17.
} 
yang menuntut kepada orang lain atas penggunaan yang tidak merugikannya atau tidak merugikan masyarakat.

Dalam diskursus hukum pidana, nilai-nilai moral dapat dijadikan sebagai justifikasi terhadap kriminalisasi suatu perbuatan. Artinya perbuatan yang immoral dapat dilegalisasi oleh legislatif menjadi perbuatan kriminal atau tindak pidana. Ketika perbuatan immoral tidak dikriminalisasi, maka akan terjadi ketegangan antara hukum pidana dan moral. ${ }^{34}$ Ketegangan ini dapat terjadi karena hukum pidana akan dinilai tidak bisa menjaga nilai-nilai moral yang dijunjung tinggi dalam pergaulan hidup masyarakat. 35

Mungkin ada sejumlah perilaku yang dipandang tidak baik atau bahkan buruk dalam masyarakat akan tetapi karena tingkat ancamannya pada masyarakat dipandang tidak terlalu besar maka perilaku tersebut tidak dirumuskan sebagai suatu tindak pidana. Menurut Oemar Seno Aji, hal semacam ini juga mencerminkan bentuk atau kualitas hubungan antara hukum pidana dan ukuran ukuran moral (moral standards). Perumusan tindak pidana semacam ini dimaksudkan untuk menjaga moral dalam masyarakat. ${ }^{36}$ Jika diimplementasikan, maka pelanggaran terhadap hak cipta bisa dikatakan sebagai perbuatan yang melanggar moralitas yang hidup dalam masyarakat karena merupakan tindakan mengambil hak orang lain tanpa seizin pemiliknya.

Jay A Singler berpendapat bahwa kriminalisasi tidak hanya bisa dilakukan terhadap perbuatan yang menimbulkan bahaya terhadap masyarakat saja, namun juga terhadap perbuatan yang menggangu dan memalukan. Menurutnya pelanggaran terhadap hak cipta dapat dikriminalisasikan karena termasuk dalam kejahatan terhadap hak kepemilikan orang lain. ${ }^{37}$

Berdasarkan uraian di atas, kriminalisasi terhadap pelanggaran hak cipta memiliki dasar legitimasi yang kuat, namun perlu di perhatikan pula bahwa sesuai dengan Pasal 56 UUHC 2002, perlindungan hukum terhadap hak cipta menurut selain bersifat pidana, juga bersifat perdata. Hanya saja, untuk

\footnotetext{
${ }^{34}$ Salman Luthan, Op. Cit., hlm. 72.

35 Romli Atmasasmita, Bunga Rampai Kriminologi, CV. Rajawali, Jakarta, 1984, hlm. 56-57.

${ }^{36}$ Harkristuti Harkrisnowo dalam Jaenal Aripin dan M. Arskal Salim (ed.), Pidana Islam di Indonesia; Peluang, Prospek, dan Tantangan, Penerbit Pustaka Firdaus, Pejaten Barat, 2001, hlm. 180.

37 Jaya A. Singler, Understanding Criminal Law, Little, Brown and Company, United States of America, tanpa tahun, hlm. 12-13.
} 
mengajukan gugatan perdata forumnya pada pengadilan niaga, sehingga tidak bisa digabungkan dengan perkara pidananya. Sistem peradilan yang demikian ini sangat tidak efektif. Oleh karena itu idealnya perkara pelanggaran hak cipta cukup diselesaikan melalui pengadilan pidana saja, dengan memasukkan ganti rugi sebagai salah satu alternatif pidananya. Sistem sanksi ganti rugi ini memang sekarang sedang direncanakan untuk bisa masuk dalam hukum pidana sebagai pidana tambahan, karena tidak mustahil suatu tindak pidana dapat merugikan korban secara materiil, termasuk dalam pelanggaran hak cipta ini dimana potensi kerugian korban secara materiil bisa sangat besar.

\section{Perumusan Kualifikasi Yuridis Delik}

Dalam WvS Belanda (1886) terdapat pembagian tindak pidana menjadi dua, yaitu kejahatan dan pelanggaran, yang berdasarkan asas concordatie dioper ke dalam WvS Hindia Belanda (1918) yang kini menjadi KUHP. Pembagian itu didasarkan pada alasan bahwa pada kenyataannya di dalam masyarakat banyak terdapat perbuatan-perbuatan yang pada dasarnya atau menurut sifatnya memang sudah tercela dan pantas untuk dipidana, meskipun sebelum dinyatakan demikian oleh undang-undang. Inilah yang masuk dalam kategori kejahatan (rechtsdelicten/mala perse). Sementara yang dikategorikan sebagai pelanggaran (wetsdelicten/mala prohibita) adalah perbuatan yang baru bersifat melawan hukum dan pelakunya dapat dipidana setelah undang-undang menyatakan demikian. ${ }^{38}$ Pandangan tersebut, dalam kepustakaan dikenal dengan perbedaan yang bersifat kualitatif. Pada masa sekarang sudah banyak ditinggalkan dan diganti dengan pandangan bahwa hanya ada perbedaan kuantitatif dalam tindak pidana, yaitu soal berat atau ringannya ancaman pidana. ${ }^{39}$

Pengaturan mengenai kualifikasi delik ini, apakah itu kejahatan atau pelanggaran, dalam berbagai Undang-Undang HKI tidak memiliki keseragaman. Dari tujuh Undang-Undang HKI di Indonesia, hanya Undang-Undang No. 29

38 Adami Chazawi, Pelajaran Hukum Pidana Bagian 1; Stelsel Pidana, Tindak Pidana, Teori teori Pemidaan dan Batas Berlakunya Hukum Pidana, Rajawali Pers, Jakarta, 2002, hlm. 120.

${ }^{39}$ Moeljatno, Asas-Asas Hukum Pidana, PT Rineke Cipta, Jakarta, hlm. 72. 
Tahun 2000 tentang Perlindungan Varietas Tanaman (UU PVT) dan UndangUndang No. 15 Tahun 2001 tentang Merek (UU Merek) yang secara eksplisit menentukan kualifikasi yuridis deliknya. Kedua undang-undang itupun memiliki kualifikasi delik yang berbeda. Tindak Pidana Perlindungan Varietas Tanaman dinyatakan sebagai kejahatan ${ }^{40}$, sedangkan UU merek dikualifikasikan sebagai pelanggaran. ${ }^{41}$ Jadi, selain UU PVT dan UU Merek, tidak ada ketentuan kualifikasi yuridis deliknya, termasuk UUHC 2002. Sebenarnya UUHC 1982 sudah menentukan kualifikasi delik tindak pidana hak cipta, yaitu sebagai kejahatan, namun pada UUHC 2002 justru tidak mengaturnya. Oleh karena itu, bisa dikatakan dalam hal pengkualifikasian yuridis delik, UUHC 2002 mengalami kemunduran.

Kalau berpandangan bahwa KUHP sebagai induk dari seluruh UU yang memiliki bersanksi pidana, maka kejahatan dan pelanggaran harus dimunculkan karena memiliki konsekwensi yuridisnya. Jan Remmelink merincinya sebagai berikut: a. perumusan delik dalam pelanggaran umumnya dilakukan secara lebih singkat (sober). Terlepas dari beberapa pengecualian, soal kesengajaan atau kesalahan jarang disinggung dalam pelanggaran; b. pelanggaran lazimnya tidak diancam dengan pidana penjara; c. perbedaan dalam hal pelanggaran adalah percobaan untuk melakukan pelanggaran, tindakan persiapan (voorbereiding) dan pembantuan (mediplichtigheid) tidak diancam dengan pidana; $d$. keputusan sendiri yang diambil oleh pengadilan-atas dasar permohonan OM-terhadap terdakwa yang menghadapi investigasi keuangan menurut hukum pidana untuk membayar sejumlah uang tertentu kepada negara dalam rangka perampasan keuntungan yang diperoleh secara melawan hukum, hanya dimungkinkan jika yang dilakukan itu adalah kejahatan; e. pengaduan sebagai syarat bagi penuntutan dalam delik aduan tidak ditemukan dalam hal pelanggaran; $f$. perbarengan tindak pidana (concursus: meerdaadse samenloop) kejahatan, sepanjang berkenaan dengan pidana penjara atau kurungan hanya memperkenankan komulasi yang terbatas. Berbeda dengan perbarengan dalam pelanggaran, pidana dapat dikomulasikan secara tidak terbatas sepanjang merupakan pidana denda;

${ }^{40}$ Lihat Pasal 75 Undang-Undang No. 29 Tahun 2000 tentang Perlindungan Varietas Tanaman.

${ }^{41}$ Lihat Pasal 94 ayat (2) Undang-Undang No. 15 Tahun 2001 tentang Merek. 
g. jangka waktu kadaluarsa pelanggaran lebih singkat (2 tahun); h. untuk pelanggaran, perkara residivis kerap sekali diatur sendiri. ${ }^{42}$

Dengan demikian, tidak adanya penetapan kualifikasi yuridis yang jelas dapat menimbulkan masalah yuridis dalam praktik, baik dari aspek yuridis materiil maupun dari aspek yuridis formal. Hal ini berarti dapat mempengaruhi efektivitas penegakkan hukum. ${ }^{43}$

\section{Rumusan Jenis Delik}

Dalam sistem KUHP Indonesia, terdapat pembagian jenis delik menjadi delik biasa dan delik aduan. ${ }^{44}$ Dalam Buku Kesatu KUHP tidak diatur tindak pidana spa saja yang termasuk dalam delik aduan. Delik-delik tersebut tersebar dalam pasal-pasal tertentu di Buku Kedua KUHP. Delik aduan hanya dikenal dalam kejahatan dan tidak untuk pelanggaran. Dari sejarah KUHP (Memorie van Toelichting) dapat ketahui bahwa munculnya syarat pengaduan berkaitan dengan kemungkinan pihak korban menderita kerugian lebih besar bila perkara tersebut ditindaklanjuti dengan penuntutan pidana. Selain itu, dalam hal pelanggaran, sisi negatif dari dilakukannya penuntutan pidana dianggap tidak begitu besar. ${ }^{45}$

UUHC 2002 tidak menegaskan bahwa tindak pidana hak cipta merupakan delik aduan. Oleh karena itu, tindak pidana hak cipta masuk dalam kualifikasi delik biasa. Suatu tindak pidana bisa dikatakan sebagai delik aduan sepanjang ditegaskan dalam KUHP atau undang-undang pidana di luar KUHP. Sementara jika tidak ada penegasan, maka otomatis suatu tindak pidana masuk dalam kualifikasi delik biasa.

Indonesia sebagai Negara yang telah meratifikasi TRIPs mengklasifikasikan hak cipta sebagai bagian dari rezim HKI karena TRIPs juga mengatur demikian. Kalau menganggap hak cipta dan hak-hak lain yang terkait,

42 Jan Remmelink, Hukum Pidana; Komentar Atas Pasal Pasal Terpenting dari Kitab Undang-Undang Hukum Pidana Belanda dan Padanannya dalam Kitab Undang-Undang Hukum Pidana Indonesia, Gramedia Pustaka Utama, Jakarta, 2003, hlm. 68-69.

${ }^{43}$ Barda Nawawi Arief, Op.Cit., hlm. 122.

44 Delik Biasa adalah jenis tindak pidana yang penyidikan ataupun penuntutannya tidak dibutuhkan syarat adanya pengaduan. Sementara delik aduan adalah jenis tindak pidana yang diperbolehkan adanya penyidikan mapun penentutan jika ada pengaduan. Tanpa adanya pengaduan, tindak pidana ini tidak bisa dilakukan penyidikan atau penuntutan.

${ }^{45}$ Jan Remmelink, Op.Cit., hlm. 418. 
serta hak milik perindustrian sama-sama merupakan bagian dari rezim HKI, maka pengaturan dalam regulasinya seharusnya juga seragam. Kalau satu regulasi mengklasifikasikan pelanggarannya sebagai delik aduan, maka seharusnya semuanya dikualifikasikan sebagai delik aduan, termasuk hak cipta. Dengan demikian, kalau dilihat konsistensi pengaturannya maka pembuat undang-undang dapat dikatakan tidak konsisten.

Dalam Risalah Sidang UU Hak Cipta, salah satu alasan pemerintah memasukkan tindak pidana hak cipta sebagai delik biasa agar aparat penyidik dapat mengambil tindakan tanpa terlebih dahulu ada laporan atau pengaduan dari pemegang hak. Pada saat UUHC dibuat, pelanggaran hak cipta di Indonesia sudah sangat massif sehingga dapat merendahkan harkat dan martabat bangsa Indonesia. Secara prinsip, pemerintah tidak berkeberatan jika untuk bidangbidang tertentu HKI, seperti paten dan merek diberlakukan delik aduan sebagaimana yang diusulkan oleh beberapa fraksi di DPR pada saat pembahasan RUU Hak Cipta. Sedangkan untuk pelanggaran hak cipta tetap menjadi delik biasa karena pelanggaran hak cipta sangat mudah dilakukan secara massal yang pada akhirnya merugikan konsumen dan Pemerintah. ${ }^{46}$

Kalau hak cipta diklasifikasikan sebagai delik biasa karena dianggap paling banyak dilanggar, maka rezim HKI yang lain seperti desain industri juga banyak pelanggarannya. Persoalan banyaknya pelanggaran sebenarnya disebabkan budaya masyarakat yang masih banyak pembajakan bukan jenis hak kekayaan intelektualnya. Dengan demikian, semuanya sama-sama terancam untuk dibajak, bukan hanya hak cipta.

Persoalan pengklasifikasian delik ini sebenarnya juga sempat menjadi perdebatan dalam pembahasan RUU Hak Cipta. Fraksi PBB berpendapat bahwa dalam praktiknya, tindak pidana hak cipta yang dikualifikasikan sebagai delik biasa selama ini justru menimbulkan ketidaktenangan dan keresahan bagi para pengusaha dan pedagang karena kesempatan ini dimanfaatkan oleh oknumoknum penegak hukum untuk mengintimidasi dan "mengintip-intip" serta mengintrogasi pedagang mengenai adanya dugaan pelanggaran hak cipta atas barang dagangannya. Hal ini yang terkena terutama pedagang-pedagang kecil di

46 Risalah Sidang Pembahasan RUU Hak Cipta, 2002. 
tingkat eceran dan grosir. Praktik yang demikian tentunya merugikan para pedagang. Dengan pengkualifikasian sebagai delik aduan sebenarnya lebih mempermudah penarikan aduan manakala telah terjadi perdamaian di antara pelaku dan korban. ${ }^{47}$

Pengklasifikasian tindak pidana hak cipta sebagai delik biasa juga dapat menimbulkan beberapa permasalahan.88 Pertama, aparat penegak hukum tidak akan bisa menentukan apakah telah terjadi tindak pidana hak cipta tanpa membandingkan barang hasil pelanggaran hak cipta dengan ciptaan aslinya. Hanya pencipta atau pemegang hak ciptanyalah yang memegang dan mengetahui dengan pasti ciptaan yang asli tersebut. Oleh karena itu, seharusnya tidak mungkin aparat penegak hukum dapat bergerak sendiri tanpa adanya pengaduan terlebih dahulu dari pencipta atau pemegang hak cipta yang merasa dirugikan atas tindak pidana tersebut.

Kedua, dalam melakukan proses hukum, aparat penegak hukum tidak mungkin langsung mengetahui apakah suatu pihak telah mendapat izin untuk mengumumkan atau memperbanyak suatu ciptaan. Oleh karena itu, pasti ada pengaduan terlebih dahulu dari pencipta atau pemegang hak cipta yang mengetahui dengan pasti bahwa sutu pihak telah melanggar hak ciptanya karena tidak memiliki izin untuk mengumumkan atau memperbanyak ciptaannya.

Ketiga, dalam praktiknya, apabila terjadi pelanggaran hak cipta, pihak yang hak ciptanya dilanggar lebih menginginkan adanya ganti rugi dari pihak yang melanggar hak cipta ketimbang pelanggar hak cipta tersebut dikenakan pidana penjara atau denda. Oleh karena itu, penyelesaiannya diupayakan secara damai di luar pengadilan.

Selain itu, masyarakat Indonesia yang bercorak ketimuran lebih mengedepankan nilai-nilai kebersamaan (komunal). Hal ini berakibat pada asumsi bahwa jika mereka berkarya dan hasil karyanya bermanfaat bagi orang banyak mereka akan merasa bangga dan tidak begitu mempermasalahkan apabila ternyata menirunya bahkan merasa diuntungkan karena hasil karyanya telah

${ }^{47}$ Risalah Sidang Pembahasan RUU Hak Cipta, 2002.

48 Ari Juliano Gema. “Tindak Pidana Hak Cipta: Lebih Baik Delik Biasa atau Delik Aduan?” Dalam http://ikastara.info/?s=dimana yang direkam pada 1 April 2008. 
disebarluaskan dan dikenal oleh banyak orang. ${ }^{49}$ Sebagai suatu hubungan privat, maka untuk mempertahankan haknya dapat dilakukan oleh pihak yang dirugikan. Namun apabila pihak yang dirugikan tidak mempergunakan haknya, maka perlindungan hukum yang telah disediakan dianggap tidak digunakan, misalnya ciptaan berupa lagu yang setelah beberapa bulan dinyanyikan dan tidak lagi ada penggemarnya, sedangkan jangka waktu perlindungannya masih ada dan penciptanya tidak mempermasalahkan bahkan bangga kalau ciptaannya ditiru orang meskipun tanpa izinnya. ${ }^{50}$

\section{Penutup}

Berdasarkan pembahasan pada bab sebelumnya, dapat disimpulkan bahwa teori yang menjadi justifikasi kriminalisasi terhadap pelanggaran hak cipta adalah teori liberal-individualistik dan teori moral. Aspek kerugian dalam pelanggaran hak cipta yang menjadi dasar dari teori liberal-individualistik didasarkan pada teori hukum alam (the natural right), reward theory, recovery theory, incentive theory, dan risk theory. Berdasarkan teori-teori tersebut, pencipta berhak mendapatkan perlindungan terhadap karya cipta yang telah diciptakan melalui suatu proses yang memerlukan tenaga dan pikiran bahkan modal yang bersifat materi. Dengan dilanggarnya hak pencipta, berarti pencipta telah dirugikan. Selain teori liberalindividualistik, teori moral juga dapat menjadi justifikasi kriminalisasi terhadap pelanggaran terhadap hak cipta karena melanggar hak cipta berarti mengambil hak orang lain tanpa seizin pemiliknya dan perbuatan tersebut merupakan perbuatan immoral.

Dalam hal kualifikasi yuridis deliknya, UUHC 2002 tidak menyebutkan secara tegas, apakah termasuk kejahatan atau pelanggaran. Tidak adanya penetapan kualifikasi yuridis dapat menimbulkan masalah hukum dalam praktiknya, baik dari aspek yuridis materiil maupun dari aspek yuridis formal. Sementara terkait dengan kebijakan perumusan jenis deliknya, UUHC 2002

\footnotetext{
49 M. Syamsudin, "Nilai Nilai Karya Cipta dan Problematika Perlindungan Hukumnya" dalam Jurnal Hukum, Fakultas Hukum UII, No. 16, Vol. 8, 2001, hlm. 133.

50 Trisno Raharjo, Kebijakan Legislatif dalam Pengaturan Hak Kekayaan Intelektual dengan Sarana Penal, Penerbit Kantor Hukum, Yogyakarta, 2006, hlm. 6.
} 
menentutakan bahwa tindak pidana hak cipta bukan merupakan delik aduan melainkan delik biasa. Dalam hal ini nampak sekali ketidakkonsistenan pembuat undang-undang karena ketentuan undang-undang HKI selain hak cipta semuanya menentukan bahwa tindak pidananya sebagai delik aduan. Pengkategorian tindak pidana hak cipta sebagai delik biasa dalam praktiknya dapat menyebabkan permasalahan dalam penegakan hukum.

\section{Daftar Pustaka}

Adami Chazawi, H., Tindak Pidana Hak atas Kekayaan Intelektual (HAKI), Bayumedia Publishing, Malang, 2007.

A. Singler, Jaya, Understanding Criminal Law, Little, Brown and Company, United States of America, tanpa tahun.

Aripin, Jaenal dan M. Arskal Salim (ed.), Pidana Islam di Indonesia; Peluang, Prospek, dan Tantangan, Penerbit Pustaka Firdaus, Pejaten Barat, 2001.

Atmasasmita, Romli, Bunga Rampai Kriminologi, CV. Rajawali, Jakarta, 1984.

Auteurswet 1912.

Chazawi, Adami, Pelajaran Hukum Pidana Bagian 1; Stelsel Pidana, Tindak Pidana, Teori teori Pemidaan dan Batas Berlakunya Hukum Pidana, Rajawali Pers, Jakarta, 2002.

Djumhana, Muhammad dan R. Djubaedillah, Hak Milik Intelektual; Sejarah, Teori, dan Prakteknya di Indonesia, Penerbit PT. Citra Aditya bakti, Bandung, 2003.

Hanitijo Soemitro, Ronny, Metodologi Penelitian Hukum, Ghalia Indonesia, Jakarta Timur, 1985.

Indonesia, Undang-Undang No. 19 Tahun 2002 tentang Hak Cipta.

Indonesia, Undang-Undang No. 15 Tahun 2001 tentang Merek.

Indonesia, Undang-Undang No. 29 Tahun 2000 tentang Perlindungan Varietas Tanaman.

Indonesia, Undang-Undang No. 7 Tahun 1994 tentang Ratifikasi Agreement on Trade Related Aspects of Intellectual Property Right (TRIPs).

Jened, Rahmi, Hak Kekayaan Intelektual Penyalahgunaan Hak Eksklusif, Airlangga University Press, Surabaya, 2007.

, Perlindunungan Hak Cipta Pasca TRIPs, Fak. Hukum Unair, Surabaya, 2001.

Juliano Gema, Ari, “Tindak Pidana Hak Cipta: Lebih Baik Delik Biasa atau Delik Aduan?" Dalam http://ikastara.info/?s=dimana yang direkam pada $1 \mathrm{Apr}$ 2008 12:35:21 GMT. 
Kadir Muhammad, Abdul, Hukum dan Penelitian Hukum, PT Citra Aditya Bakti, Bandung, 2004.

Leaffer, Marshal, Understanding Copyright Law Mattew, Bender, New York, 1998.

M. Sherwood, Robert, Intellectual Property and Economic Development, Alexandria, Virginia, 1990.

Mandhavan, Mahesh, "Intellectual Property Rights: An Overview" dalam JISC Legal Journal, March 2006.

Moeljatno, Asas-Asas Hukum Pidana, PT Rineke Cipta, Jakarta.

Nawawi Arief, Barda, Kapita Selekta Hukum Pidana, PT. Citra Aditya Bakti, Bandung, 2003.

Raharjo, Trisno, Kebijakan Legislatif dalam Pengaturan Hak Kekayaan Intelektual dengan Sarana Penal, Penerbit Kantor Hukum, Yogyakarta, 2006.

Remmelink, Jan, Hukum Pidana; Komentar Atas Pasal Pasal Terpenting dari Kitab Undang-Undang Hukum Pidana Belanda dan Padanannya dalam Kitab UndangUndang Hukum Pidana Indonesia, Gramedia Pustaka Utama, Jakarta, 2003.

Risalah Sidang Pembahasan RUU Hak Cipta, 2002.

Saidin, OK., Aspek Hukum Hak Kekayaan Intelektual (Intellectual Property), Raja Grafindo Persada, Jakarta, 2006.

Soekanto, Soerjono, Pengantar Penelitian Hukum, UI Press, Jakarta, 2005.

Sudarto, Hukum dan Hukum Pidana, Alumni, Bandung, 1981.

Syafrinaldi, Hukum Tentang Perlindungan Hak Milik Intelektual Dalam Menghadapi Era Globalisasi, UIR Press, Pekanbaru, 2001.

Syamsudin, M., Operasionalisasi Penelitian Hukum, PT RajaGrafindo Persada, Jakarta, 2007.

"Nilai Nilai Karya Cipta dan Problematika Perlindungan Hukumnya." Dalam Jurnal Hukum, Fakultas Hukum UII, No. 16, Vol 8, 2001.

Tim Lindsey dkk (ed.), Hak Kekayaan Intelektual Suatu Pengantar, P.T Alumni, Bandung, 2002.

Universal Declaration of Human Right 1948.

van Apeldoorn, L. J., Pengantar Hukum Indonesia, PT Pradnya Paramita, Jakarta, 2000. 